\title{
Effect of Safety Measures on Bacterial Contamination Rates of Blood Components in Germany
}

\author{
Gabriele Walther-Wenke $^{a}$ Walter Däubener ${ }^{b}$ Margarethe Heiden ${ }^{c}$ Jochen Hoch ${ }^{d}$ \\ Britt Hornei $^{\mathrm{e}}$ Peter Volkers ${ }^{c}$ Carl Heinz Wirsing von König ; Working Party on Bacteria Safety \\ in Transfusion Medicine of the National Advisory Committee Blood of the German Federal \\ Ministry of Health (Arbeitskreis Blut), Berlin, Germany
}

\footnotetext{
a Zentrum für Transfusionsmedizin Münster, DRK-Blutspendedienst West, Münster,

${ }^{b}$ Institut für Medizinische Mikrobiologie und Krankenhaushygiene, Heinrich-Heine-Universität Düsseldorf,

${ }^{c}$ Paul-Ehrlich-Institut, Bundesinstitut für Impfstoffe und biomedizinische Arzneimittel, Langen,

d Institut für Experimentelle Hämatologie und Transfusionsmedizin. Universitätsklinikum Bonn,

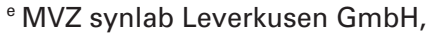

${ }^{\dagger}$ Helios Klinikum Krefeld, Institut für Hygiene und Laboratoriumsmedizin, Krefeld, Germany
}

\section{Keywords}

Bacterial contamination · Blood components .

Contamination rate $\cdot$ Quality control

\section{Summary}

Requirements for bacterial testing of blood components on a defined quantity as part of routine quality control were introduced in Germany by the National Advisory Committee Blood of the German Federal Ministry of Health in 1997. The philosophy was to establish standardized methods for bacterial testing. Numerous measures to reduce the risk of bacterial contamination were implemented into the blood donation and manufacturing processes between 1999 and 2002. German Blood establishments performed culturebased bacterial testing on random samples of platelet concentrates (PCs), red blood cells (RBCs) and fresh frozen plasma (FFP) and reported data out of the production periods 1998, 2001 and 2005/2006. While the bacterial contamination rate of apheresis PCs remained nearly unchanged, it decreased by $70 \%$ for pooled PCs to a rate of $0.158 \%$ in the last observation period. Leukocyte-depleted RBCs with diversion of the initial blood volume showed a contamination rate of $0.029 \%$ which is significantly lower than that of RBCs without leukocyte depletion and diversion (0.157\%). The contamination rate of plasma decreased by $80 \%$. Preventive measures resulted in a significant reduction of bacterial contamination of blood components. Long-term monitoring with standardized methods for bacteria testing supports evaluation of the cumulative effect of contamination reducing measures.

\author{
Schlüsselwörter \\ Bakterielle Kontamination - Blutkomponenten . \\ Kontaminationsrate · Qualitätskontrolle
}

\section{Zusammenfassung}

In Deutschland wurde 1997 mit einem Votum des Arbeitskreises Blut die Prüfung von Blutkomponenten auf bakterielle Kontamination an einer definierten Stichprobe als Bestandteil der Qualitätskontrolle eingeführt. Ziel war die Etablierung standardisierter Methoden zur Testung auf Bakterien. Zwischen 1999 und 2002 wurde eine Reihe von Maßnahmen in die Prozesse bei der Blutspende und Komponentenherstellung integriert, um das Risiko der bakteriellen Kontamination zu reduzieren. Die Blutspendedienste führten an einer Zufallsstichprobe von Thrombozytenkonzentraten, Erythrozytenkonzentraten und Plasmen eine Testung auf Bakterien mittels Kulturverfahren durch und berichteten ihre Ergebnisse aus den Produktionszeiträumen 1998, 2001 und 2005/2006. Während die bakterielle Kontaminationsrate bei Apherese-Thrombozytenkonzentraten nahezu unverändert blieb, sank die Rate bei PoolThrombozytenkonzentraten um $70 \%$ auf $0,158 \%$ im letzten Beobachtungszeitraum. Leukozytendepletierte Erythrozytenkonzentrate mit Abtrennung des initialen Blutvolumens bei der Blutspende zeigten mit einer Kontaminationsrate von $0,029 \%$ eine signifikante Abnahme des Bakterieneintrags gegenüber Konzentraten ohne Leukozytendepletion und Diversion mit einer Rate von 0,157\%. Die Kontaminationsrate von Plasma nahm um $80 \%$ ab. Präventive Maßnahmen führten zu einer signifikanten Reduktion des Bakterieneintrags in Blutkomponenten. Die Langzeitbeobachtung mit standardisierten Testmethoden ermöglicht die Bewertung des kumulativen Effekts kontaminationsreduzierender Maßnahmen.

\section{KARGER}

Fax +497614520714

Information@Karger.de

www.karger.com (c) 2011 S. Karger GmbH, Freiburg

Accessible online at:

www.karger.com/tmh 


\section{Introduction}

Transfusion-associated bacterial infection still is a serious risk of morbidity and mortality related to blood transfusion. In the past decades various measures have been implemented in blood establishments to reduce this hazard and to improve bacterial safety of blood components.

For the purpose of donor screening, separately obtained blood samples can be tested by serological and molecular biological techniques. The resulting progress in terms of reduced risk of viral transmission, in particular, contrasts with a still relatively high risk of transfusion reactions due to bacteria in blood components.

In a first retrospective survey performed in 1997, data on bacterial contamination of blood components in Germany during the production period 1995/1996 were obtained [1]. The participating blood establishments employed highly variable methods in terms of time of sampling, sample volume, incubation temperature and incubation time. Both conventional culture methods with liquid and solid media and automated methods were used. In 1997 the working party on bacteria safety in transfusion medicine of the National Advisory Committee Blood of the German Federal Ministry of Health (Arbeitskreis Blut) introduced national guidelines to monitor bacterial contamination of blood components as part of routine quality control in all blood establishments [2].

The intention of these guidelines was to establish standardized methods for bacterial testing to gain data on a broad basis for observation and analysis of contamination rates over long time periods. In this article, we present an overview on the results of bacterial testing of blood components in German blood establishments in the production periods 1998, 2001 and 2005/2006, and focus on the influence of precautionary measures implemented to reduce bacterial contamination.

\section{Contamination Reduction Measures}

General and specific measures to prevent bacterial contamination were introduced in Germany between 1999 and 2002. Integrity testing of sterile tubing welds to identify leakages is mandatory since 1999 [3]. All tube connections have to be checked by a tube stripping device test procedure as part of in-process control. Details on careful donor selection and on skin cleansing procedures were introduced by revised guidelines on the collection of blood and blood components in 2000 [4]. The donor questionnaire was amended by questions on diarrhea, dental treatments, abscesses and osteomyelitis as risk factors for asymptomatic bacteremia. Skin disinfection has to be performed by double application of a licensed and certified antiseptic and a defined exposure time. Starting from October 2001 leukocyte depletion of cel-
Table 1. Contamination rates of PCs by bacterial testing as part of routine quality control

\begin{tabular}{llcl} 
Type of PC & $\begin{array}{l}\text { Production } \\
\text { period }\end{array}$ & $\begin{array}{l}\text { Number } \\
\text { tested }\end{array}$ & $\begin{array}{l}\text { Contamination rate } \\
\text { (confirmed positive) in \% }\end{array}$ \\
\hline APCs & 1998 & 4,523 & 0.155 \\
APCs & 2001 & 8,302 & 0.157 \\
APCs & $2005 / 2006$ & 11,452 & 0.114 \\
PPCs & 2001 & 3,947 & 0.507 \\
PPCs & $2006 / 2006$ & 8,850 & 0.158 \\
\hline Data published in: Vox Sang 2006;90:177-182 and Vox Sang \\
2011;100:356-366.
\end{tabular}

lular blood components was introduced as a general requirement [5].

Diversion of the initial blood volume prior to blood collection was implemented in 2002 [6].

\section{Bacterial Contamination of Platelet Concentrates}

Results of bacterial testing of platelet concentrates (PCs) at the end of shelf life derived from single platelet concentrates (SPCs) prepared from whole blood, pooled platelet concentrates (PPCs) prepared from four buffy coats and from apheresis platelet concentrates (APCs). The authors analyzed whether the contamination rates of PCs in the 3 surveys were influenced by production methods such as apheresis, pooling, leukocyte depletion and diversion [7, 8].

APCs showed a nearly constant contamination rate over all study periods (table 1). The authors concluded that diversion and leukocyte depletion seem to have no significant impact on the frequency of bacterial contamination of APCs.

Leukocyte depletion of cellular blood components as a general requirement induced a change in manufacturing processes of PCs from whole blood-derived single-unit PCs to buffy coat-derived and leukocyte-depleted PCs as one therapeutic unit. While $0.507 \%$ out of 3,947 PPCs tested in 2001 turned out to be contaminated, 8,850 PPCs tested in 2005/2006 showed a contamination rate of $0.158 \%$ (table 1 ).

Diversion was not yet implemented in 2001 but in 2005/2006. Comparison of contamination rates of PPCs without and with diversion showed a $70 \%$ reduction in bacterial contamination and confirms results of a series of studies on the effect of diversion on PCs [9-11].

Since PCs are thought to be at considerably higher risk of contamination than RBC concentrates, in many countries bacterial testing of PCs was implemented. In most cases, automated culture methods such as BacT/ALERT (bioMérieux, Nürtingen, Germany) are used [12].

Comparability of data is rendered difficult by differences in the test methods used: time of sampling at the beginning or end of shelf life, sample volume, aerobic and anaerobic cul- 
Table 2. Contamination rates of $\mathrm{RBC}$ concentrates by bacterial testing as part of routine quality control

\begin{tabular}{llll}
\hline Type of RBC concentrate & $\begin{array}{l}\text { Production } \\
\text { period }\end{array}$ & $\begin{array}{l}\text { Number } \\
\text { tested }\end{array}$ & $\begin{array}{l}\text { Contamination rate } \\
\text { (confirmed positive) in \% }\end{array}$ \\
\hline RBC concentrates not leukocyte-depleted & 1998,2001 & 28,218 & 0.167 \\
RBC concentrates leukocyte-depleted, without diversion & 2001 & 27,336 & 0.087 \\
RBC concentrates leukocyte-depleted, with diversion & $2005 / 2006$ & 54,845 & 0.029 \\
\hline Data published in: Vox Sang 2011;100:356-366. & & & \\
\hline
\end{tabular}

ture versus aerobic culture only, incubation period and last but not least statistical sample size.

In several countries pre-release screening of PCs with automated culture systems was implemented to prevent issue and transfusion of contaminated platelets [9, 12-18]. Sampling for platelet surveillance cultures is performed soon after production to dispatch only PCs with negative cultures.

In Germany one study was conducted that compared contamination rates of APCs and PPCs derived from four buffy coats with sampling at the beginning of shelf life [19]. Manufacturing and testing conditions were similar to those for PCs in the 2005/2006 survey. Consistent with the survey data, contamination rates of APCs and PPCs did not differ significantly. The rate of confirmed positive PPCs with an early postproduction sampling was significantly lower than that of the $2005 / 2006$ survey $(0.06 \%$ vs. $0.157 \%)$. Sampling at the end of shelf life probably detects bacteria that were missed at the beginning of the shelf life period because of their low number in the PCs. Results are consistent with data from studies performed with re-testing of outdated PCs to determine the effectiveness of the screening for bacteria. Murphy et al. [20] reported confirmed positive results with a BacT/ ALERT screening on early sampling on $0.08 \%$ of PCs. At a follow-up test on day $4,0.12 \%$ of PCs were positive, and on testing after expiry date $0.22 \%$ of PCs showed to be contaminated. Pearce et al. [21] published comparable data, with contamination rates of $0.06 \%$ detected during initial testing of PCs and $0.09 \%$ detected by testing of outdated PCs. The authors concluded that the sensitivity of bacterial screening by early sampling is $\leq 40 \%$ because of the initially low bacterial load. As a consequence, septic transfusion reactions have been reported from PCs with initially negative screening results [13-16, 18, 19].

As described before, the purpose of sampling shortly after the date of manufacture is to detect contamination prior to transfusion. Random bacterial testing at the end of the storage period in Germany serves as a quality control method for the collection and production processes. Production methods for PCs vary from country to country and include apheresis, production of single-donor concentrates from whole blood, production of pooled concentrates from 4 to 6 single-donor concentrates in a functionally closed system with sterile tubing, bedside pooling using plug-in connections, and production from 4-6 pooled buffy coats with plasma or storage solu- tion [22]. Thus, comparability of contamination rates on an international basis is limited, not only because of different test methods but also because of different manufacturing methods for PCs. The same applies to shelf life of PCs, which varies between $72 \mathrm{~h}$ to 7 days [12].

\section{Bacterial Contamination of Red Blood Cell Concentrates}

German blood establishments performed culture-based testing on a random sample of 110,399 RBC concentrates out of a total production of $16,338,293$ RBC concentrates in the periods 1998, 2001 and 2005/2006 [7, 8]. To investigate the potential influence of leukocyte depletion, authors combined test results of $\mathrm{RBC}$ concentrates with and without leukocyte depletion (table 2). Compared to unfiltered RBC concentrates with a contamination rate of $0.167 \%$, leukocyte depletion of RBC concentrates resulted in a significant decrease to $0.087 \%$. Implementation of diversion of the initial blood flow away from the blood collection bag resulted in a further decrease of the contamination rate of $\mathrm{RBC}$ concentrates to $0.029 \%$ in the $2005 / 2006$ survey. Data indicate a favorable effect of leukocyte removal. Studies have shown that bacteria are phagocytosed by leukocytes in the whole blood storage phase and can be eliminated by leukocyte filtration [23-26].

Similar to other studies, German data showed that diversion of the initial blood flow contributes to reducing bacterial contamination of whole blood donations by skin surface bacterial [27-30]. Data on results of bacteria monitoring of timeexpired RBCs as performed in Germany were only available from the National Blood Service in England. Six confirmed positives out of 8,585 tested RBC concentrates were reported in the years 2002-2005 after implementation of leukocyte depletion and diversion, resulting in a contamination rate of $0.065 \%$ [12].

\section{Bacterial Contamination of Plasma}

Progressive reduction of the contamination rate of fresh frozen plasma (FFP) could be achieved from 1998 to 2005/2006. The combination of efforts resulted in a rate of $0.019 \%$ con- 
firmed contaminated FFP units which means a reduction of $80 \%$ when compared with the rate of $0.100 \%$ in 1998 . In contrast to cellular blood components, data from studies on frequency of bacteria in FFP are not available. Storage below freezing point and a short interval between thawing and transfusion are unfavorable conditions for survival and proliferation of bacterial [31]. Case reports of septic reactions associated with transfusion of plasma indicate that water baths can cause microbial entry during thawing process [32,33].

\section{Bacterial Species}

Determination of bacterial species detected in the 3 surveys showed that organisms predominantly belong to the transient and resident skin flora. Gram-positive bacteria from the common skin flora also presented the majority of species in published studies. Fast growing Gram-negative bacteria known to include some of the most clinically significant organisms were not isolated from blood component in the three surveys.

The authors contribute this to the fact that these bacteria rarely occur as contaminants of blood components and therefore were not detected in the sample.

Gram-negative organisms tend to cause more severe reactions, due to presence of endotoxins often produced by such organisms [34, 35]. However, all detected bacterial species may induce transfusion-associated complications depending on the bacterial load and on the patient's condition.

\section{Conclusions}

Data on routine quality control testing on a random sample of blood components according to specified guidelines provide a basis for monitoring bacterial contamination over long time periods. As previously described, numerous measures were introduced in the collection and manufacturing of blood components between 1997 and 2002 to prevent bacterial contamination. As no head-to-head comparison was possible, contamination rates of the different production periods and of different products were used to estimate the effect of leukocyte depletion for RBC concentrates or PCs and of diversion for RBC concentrates, PCs or FFP. Preventive measures resulted in a significant reduction of bacterial contamination of blood components. Nevertheless, transfusion of bacterially contaminated components, especially platelets, is an ongoing risk. The procedures currently used in obtaining and manufacturing blood components seem to offer no further potential for improvement.

\section{Acknowledgement}

We thank participating blood establishments for their collaboration.

\section{Disclosure Statement}

The authors declared no conflict of interest.

\section{References}

1 Walther-Wenke G, Doerner R, Montag-Lessing T, Lange H, B, Daeubener W, et al: Bacterial contamination of blood components: results of a two-year survey in Germany (abstract). Transfusion 1999;39 (suppl 1):22.

2 Arbeitskreis Blut: Mindestanforderungen zur Sterilitätstestung von Blutkomponenten. 23. Sitzung des Arbeitskreises Blut am 05.06.1997. Bundesgesundheitsblatt 1997;8:307-309.

3 Arbeitskreis Blut: Herstellung kontaminationssicherer Schlauchverbindungen bei Blutbeuteln 31. Sitzung des Arbeitskreises Blut am 02.12.1998. Bundesgesundheitsblatt 1998;41:2.

4 Bundesärztekammer, Paul-Ehrlich-Institut: Richtlinien zur Gewinnung von Blut und Blutbestandteilen und zur Anwendung von Blutprodukten (Hämotherapie) Gesamtnovelle 2005 mit Richtlinienanpassung 2010. Köln, Deutscher Ärzteverlag, 2010.

5 Arbeitskreis Blut: Zusätzliche Risikovorsorge bei Blutspenden: Beschleunigte Einführung der Leukozytendepletion und Spenderausschluss bei mehr als sechsmonatigem Aufenthalt im Vereinigten Königreich. Bundesgesundheitsbl Gesundheitsforsch Gesundheitsschutz 2001;44:110-111.

6 Arbeitskreis Blut: Einführung des Predonation Samplings. 48. Sitzung des Arbeitskreises Blut am 26.06,2002. Bundesgesundheitsblatt 2002;45:756 (English version: www.rki.de).
7 Walther-Wenke G, Doerner R, Montag T, et al: Bacterial contamination of platelet concentrates prepared by different methods: results of standardized sterility testing in Germany: Vox Sang 2006; 90:177-182.

8 Walther-Wenke G, Wirsing von König CH, Daeubener W, et al: Monitoring bacterial contamination of blood components in Germany: effect of contamination reduction measures. Vox Sang 2011; 100:356-366.

9 de Korte D, Curvers J, de Kort WLAM, et al: Effects of skin disinfection method, deviation bag, and bacterial screening on clinical safety of platelet transfusions in the Netherlands. Transfusion 2006; 46:476-485.

10 Mc Donald CP: Bacterial risk reduction by improved donor arm disinfection, diversion and bacterial screening. Transfus Med 2006;16:381-396.

11 Benjamin RF, Kline L, Dy BA, et al: Bacterial contamination of whole blood-derived platelets: the introduction of sample diversion and prestorage pooling with culture testing in the American Red Cross. Transfusion 2008;48:2348-2355.

12 International Forum: Detection of bacterial contamination of platelet concentrates. Vox Sang 2007; 93:260-277.

13 te Boekhorst PAW, Beckers EAM, Vos MC, et al: Clinical significance of bacteriologic screening in platelet concentrates. Transfusion 2005;45:514-519.
14 Larsen CP, Ezligini F, Hermansen NO, et al: Six years' experience of using the BacT/ALERT system to screen all platelet concentrates, and additional testing of outdated platelet concentrates to estimate the frequency of false-negative results. Vox Sang 2005;88:93-97.

15 Ramírez-Arcos S, Jenkins C, Dion J, et al: Canadian experience with detection of bacterial contamination in apheresis platelets. Transfusion 2007; 47:421-429.

16 Eder AF, Kennedy JM, Dy BA, et al: Bacterial screening of apheresis platelets and the residual risk of septic transfusion reactions: the American Red Cross experience (2004-2006). Transfusion 2007;47:1134-1142.

17 Benjamin RJ, Wagner SJ: The residual risk of sepsis: modelling the effect of concentration on bacterial detection in two-bottle culture systems and on estimation of false-negative culture rates. Transfusion 2007;47:1381-1389.

18 Dumont LJ, Kleinmann S, Murphy JR, et al: Screening of single-donor apheresis platelets for bacterial contamination: the PASSPORT study results. Transfusion 2010;50:589-599.

19 Schrezenmeier H, Walther-Wenke G, Müller TH, et al: Bacterial contamination of platelet concentrates: results of a prospective multicenter study comparing pooled whole blood-derived platelets and apheresis platelets. Transfusion 2007;47:644-652. 
20 Murphy WG, Foley M, Doherty C, et al: Screening platelet concentrates for bacterial contamination: low numbers of bacteria and slow growth in contaminated units mandate an alternative approach to product safety. Vox Sang 2008;95:13-19.

21 Pearce S, Rowe GP, Field SP: Screening of platelets for bacterial contamination at the Welsh Blood Service. Transfus Med 2011;21:25-32.

$\checkmark 2$ International Forum: Evaluation of stored platelets. Vox Sang 2004;86:203-223.

23 Högmann CF, Engstrand L: Factors affecting growth of Yersinia enterocolitica in cellular blood products. Transfus Med Rev 1996;10:259-275.

24 Högman CF, Gong J, Erisksson I, et al: White cells protect donor blood against bacterial contamination. Transfusion 1991;31:620-626.

25 Siblini L, Lafeuillade B, Ros A, et al: Influence of blood storage conditions and white blood cell filtration on the bacterial load of blood deliberately inoculated with Gram-positive and Gram-negative pathogens. Vox Sang 2004:87:241-249.

26 Buchholz DH, AuBuchon JP, Snyder EL, et al: Effects of white cell reduction on the resistance of blood components to bacterial multiplication. Transfusion 1994;34:852-857.

27 Wagner SJ, Robinette D, Friedman LI, et al: Diversion of initial blood flow to prevent wholeblood contamination by skin surface bacteria: an in vitro model. Transfusion 2000:40:335-338.

28 Bruneau C, Perez P, Chassaigne M, et al: Efficacy of a new collection procedure for preventing bacterial contamination of whole blood donations. Transfusion 2001:41:74-81.

29 de Korte D, Marcelis JH, Verhoeven AJ, et al: Diversion of first blood volume results in a reduction of bacterial contamination for whole-blood collections. Vox Sang 2002;83:13-16.

30 McDonald CP, Roy A, Mahajan P, et al: Relative values of the interventions of díversion and improved donor-arm disinfection to reduce the bacterial risk from blood transfusion. Vox Sang 2004;86:178-182.

31 Wagner SJ, Friedman LI, Dodd RY: Transfusionassociated bacterial sepsis. Clin Microbiol Rev 1994; 7:290-302.

\$2 Casewell MW, Slater NG, Cooper JE: Operatin theatre water-baths as a cause of Pseudomonas septicaemia. J Hosp Infect 1981;2:237-247.

33 Muyldermans G, de Smet F, Pierard D: Neonatal infections with Pseudomonas aeruginosa associated with a water-bath used to thaw fresh frozen plasma. J. Hosp Infect 1998;39:309-314.

34 Hillyer CD, Josephson CD, Blajchman MA, Vostal JG, Epstein JS, Goodman JL: Bacterial contamination of blood components: risks, strategies, and regulation: joint $\mathrm{ASH}$ and $\mathrm{AABB}$ educational session in transfusion medicine. Hematology Am Soc Hematol Educ Program 2003:575-589.

35 Jacobs MR, Caryn EG, Lazarus HM, Yomtovian RA: Relationsship between bacterial load, species, virulence, and transfusion reaction with transfusion of bacterially contaminated platelets. Clin Infect Dis 2008;1214-1220. 